\title{
UPAYA MENINGKATKAN KEAKTIFAN DAN HASIL BELAJAR KESEBANGUNAN MELALUI PEMBELAJARAN MATEMATIKA REALISTIK
}

\author{
Musrifah \\ MTs Negeri 2 Temanggung \\ mrifah@gmail.com \\ DOI : http://doi.org/10.37730/edutrained.v4i2.80 \\ Diterima: 17 Agustus 2020 | Disetujui: 26 November 2020 | Dipublikasikan: 29 November 2020
}

\begin{abstract}
Abstrak
Penelitian ini bertujuan untuk meningkatkan keaktifan siswa dalam pembelajaran dan hasil belajar kesebangunan dengan Pembelajaran Matematika Realistik (PMR). Hasil belajar pada penelitian ini meliputi pemahaman konsep dan ketrampilan memecahkan masalah. Penelitian ini dilaksanakan di kelas IXE MTs Negeri 2 Temanggung. Penelitian ini merupakan penelitian tindakan kelas. Penelitian ini dilakukan dalam dua siklus. Setiap siklus terdiri dari 3 pertemuan yaitu pertemuan pertama siswa disajikan masalah yang berkaitan dengan kesebangunan, pertemuan kedua siswa difasilitasi untuk mengkontruksi konsep kesebangunan, pertemuan ketiga siswa disajikan kembali kegiatan memecahkan masalah aplikasi konsep kesebangunan. Data yang diperoleh dalam penelitian ini adalah data keaktifan siswa, data nilai pengetahuan, dan data nilai ketrampilan. Data yang diperoleh dianalisis menggunakan teknik deskripsi komparasi. Hasil yang diperoleh pada penelitian ini adalah keaktifan siswa dalam pembelajaran matematika pada siklus pertama $69,4 \%$ naik menjadi $94,4 \%$ pada siklus kedua, pemahaman konsep kesebangunan pada siklus pertama $76 \%$ naik menjadi $87 \%$ pada siklus kedua, dan kemampuan memecahkan masalah kesebangunan pada siklus pertama dan kedua mencapai $68 \%$ meningkat dari pra siklus yang hanya 34,38\%. Dari hasil tersebut penerapan pembelajaran matematika realistik pada materi kesebangunan dapat meningkatkan keaktifan dan hasil belajar siswa.
\end{abstract}

Kata kunci : pembelajaran matematika realistik, pemecahan masalah, kesebangunan

\begin{abstract}
The purpose of this research is to improve student activity dan learning outcomes trought Realistic Mathematic Education (RME). Learning outcomes involve understanding concepts and problem solving skills. This research is applied on nineth E grade of MTs Negeri 2 Temanggung. This research is conducted on two cycles. Each cycle consisted of three meetings that first meeting the students presented a problem relating to similirity, at the second meeting the students facilatated students to construct the consept of similarity, at the third meeting the students served back a problem that aplication of similarity.Data obtained in this research is data activity of students in learning, the values of knowledge and skills. The data were analiyzed by using a description comparation techniques. The results of this research are active students in the first cycle of 69,4\% increase to $94,4 \%$ in the second cycle, the understanding of similarity concept in first cycle of $76 \%$ increase $87 \%$ in the second cycle, and problem solving competencies on first and second cycle reach 68\%, increase from pre siklus 34,38\%. . From these result the aplication of realistic mathematic education to similarity can increase student activeness and learning outcomes.
\end{abstract}

Keyword : realistic mathematic education, problem solving, similarity 


\section{PENDAHULUAN}

Adanya pemberlakuan kurikulum 2013 telah membuat paradigma pembelajaran bergeser dari teacher center menjadi student center. Pembelajaran dilaksanakan agar siswa memiliki kemampuan dan kreativitas dalam memecahkan masalah yang dihadapi. Matematika merupakan salah satu mata pelajaran yang diajarkan dari tingkat SD/MI sampai perguruan tinggi. Matematika memiliki peran strategis dalam ikut membentuk siswa menjadi manusia yang siap dalam menghadapi tantangan, yaitu dengan memiliki kemampuan berfikir logis dan kemampuan memecahkan masalah. Menurut Mahmudi (2009) pembelajaran matematika tidak hanya dimaksudkan untuk melatih siswa agar menguasai meteri yang sebanyak banyaknya, melainkan juga untuk mengembangkan kemampuan berfikir.

Oleh karena itu dalam pembelajaran matematika hendaknya memberikan peluang kepada siswa agar mendapatkan pengalaman memecahkan masalah, baik masalah matematika, penerapannya dalam kehidupan sehari-hari, berfikir logis dan berinteraksi dengan orang lain untuk memecahkan masalah tersebut. Dalam hal ini dituntut kemampuan guru sebagai fasilitator agar dapat menyajikan pembelajaran yang memberikan pengalaman seperti tersebut di atas, tetapi materi dalam kurikulum juga dapat tersampaikan.

Kesebangunan dan kekongruenan merupakan konsep dasar kesebangunan yang banyak sekali aplikasi dan manfaatnya dalam kehidupan sehari-hari. Namun siswa mengalami kesulitan dan melakukan kesalahan dalam memahami konsep kesebangunan. Berdasar pengamatan hasil pekerjaan siswa pada pembelajaran kesebangunan, kesalahan-kesalahan itu antara lain adalah salah menentukan sisi-sisi yang bersesuaian sehingga menghasilkan perbandingan sisi yang tidak benar, salah dalam menentukan pasangan sudut-sudut yang sama besar, salah dalam menyebutkan sifat kenapa kedua sudut itu sama.

Pembelajaran matematika di MTs Negeri 2 Temanggung selama ini belum memberikan hasil yang baik, hal ini dapat dilihat dari hasil penilaian harian kelas IX pada tahun 2018/2019 untuk pokok bahasan kesebangunan hanya 17\% siswa yang nilainya di atas atau sama dengan KKM (kriteria ketuntasan minimal) yaitu 70 dan juga hasil UN tahun 2019 untuk kemampuan yang diuji menyelesaikan masalah yang berkaitan dengan kesebangunan atau kongruensi hanya 47,46\% masih di bawah rata-rata kemampuan Kabupaten 53,55\% untuk materi kesebangunan dan kekongruenan.

(hasilun.puspendik.kemdikbud.go.id) Berdasar hasil observasi pada saat pembelajaran matematika yang dilaksanakan menggunakan metode konvensional, siswa mengikuti pembelajaran dengan pasif, yang ditunjukkan dengan siswa yang bertanya hanya beberapa siswa, guru lebih banyak menjelaskan siswa mendengarkan sehingga transfer of knowledge berjalan searah. Hal ini yang membuat siswa jenuh dalam mengikuti pembelajaran dan mengalami kebosanan, sehingga harus dicari alternatif pembelajaran yang menyenangkan sekaligus memberikan pengalaman.

Realistik Mathematic Education (RME) atau pembelajaran matematika realistik merupakan salah satu pendekatan materi yang dapat menjadi alternatif dalam pembelajaran matematika. RME dikembangkan di Belanda oleh Fruedential Institute. Prinsip dasar dalam pembelajaran dengan RME ini adalah memberikan pengalaman pada siswa untuk menemukan kembali konsep matematika dengan menggunakan masalah kontekstual. (Marja dan Paul, 2013)

Menurut Bonotto dalam Laurens dkk (2017) RME memiliki tujuan untuk mengubah pembelajaran matematika menjadi lebih menyenangkan dan bermakna bagi siswa dengan memperkenalkan mereka ke dalam masalah dalam konteks. RME dimulai dengan mengambil masalah yang relevan dengan pengalaman dan pengetahuan siswa. Guru kemudian bertindak sebagai fasilitator untuk membantu siswa memecahkan masalah kontekstual. Kegiatan pemecahan masalah yang kontekstual ini diyakini dapat membawa dampak positif bagi prestasi 
kognitif siswa terutama terkait dengan kemampuannya dalam memahami matematika. Cara terbaik untuk mengajar matematika adalah dengan memberikan siswa pengalaman yang bermakna dengan memecahkan masalah yang mereka hadapi setiap hari atau dengan kata lain dengan menangani masalah kontekstual.

Berdasarkan latar belakang masalah di atas dapat dirumuskan masalah sebagai berikut; 1) Bagaimana pembelajaran matematika realistik dilaksanakan dalam pembelajaran Kesebangunan pada siswa kelas IX MTs Negeri 2 Temanggung. 2) Apakah dengan Realistic Mathematic Education dapat meningkatkan keaktifan siswa kelas IX MTs N 2 Temanggung dalam proses pembelajaran matematika pada pokok bahasan Kesebangunan ? 3) Apakah dengan realistic mathematic education dapat meningkatkan hasil belajar siswa?

\section{KAJIAN PUSTAKA}

\section{Realistic Mathematic Education (RME)}

Menurut Zulkardi (2010) pembelajaran matematika realistik adalah teori belajar dan mengajar dalam pembelajaran matematika yang pertama kali dikenalkan dan dikembangkan oleh Freudenthal Institute di Belanda.

Menurut Heuvel-Panhuzein (2003)

"Realistic Mathematics Education (RME) is a domain-specific instruction theory for mathematics, which has been developed in the Nedherlands. Characteristic of RME is that rich, "realistic" situations are given a prominent position in the learning process. This situation serve as a source for initiating the development of mathematical concept, tools and procedures and as a context in which students can in a later stage apply their mathematical knowledge, which then gradually has became more formal and general and less context-specific"

Menurut Zulkardi (2010) ada dua pandangan penting dalam pembelajaran matematika realistik adalah 1) matematika harus dihubungkan dengan masalah real, yaitu matematika harus dekat dengan kehidupan siswa dan relevan dengan situasi kehidupan sehari-hari. "real" tidak selalu berhubungan dengan dunia real tetapi dapat berupa masalah yang real dalam pikiran siswa atau siswa dapat membayangkannya. 2) dan matematika sebagai aktivitas manusia, yaitu pembelajaran matematika diorganisasikan sebagai proses penemuan kembali yang terbimbing, dimana siswa dapat pengalaman proses yang serupa dibanding dengan proses matematika diperoleh.

Menurut Heuvel-Panhuzein (2013):

"Althought ' realistic' situations in the meaning of 'real-wold' stuations are importing in RME, 'realistic' has broader connotation here. It means students are offered problem situations which they can imagine. This interpretation of 'realistic' traces back to the Dutch expression 'zich Realiseren' meaning to 'imagine'. Therefore, in RME, problem presented to students can come from the real word, but also from the fantasy world of fairy tales, or the formal word of mathematics, as long as the problem are experiantially real in the studet's mind"

Berdasarkan dua pendapat di atas dapat kita simpulkan bahwa ide dari RME adalah pembelajaran matematika dengan menggunakan masalah kontekstual yaitu masalah yang nyata dalam kehidupan sehari-hari dekat dengan kehidupan siswa atau masalah yang dapat dibayangkan oleh siswa. Serta siswa harus diberi peluang untuk menemukan kembali matematika dibawah bimbingan guru. Dalam hal ini masalah yang disajikan pada pembelajaran merupakan masalah yang sesuai dengan materi yang akan dipelajari, serta masalah tersebut dapat dibayangkan oleh siswa

Menurut Treffers dalam Fauzan (2002: 34) Pengetahuan matematika formal dapat dikembangkan dari pengetahuan informal siswa, Sehingga dengan menyajikan beberapa aktivitas penyelesaian masalah konstekstual yang real untuk siswa, siswa dapat menggunakan pengetahuan informalnya untuk menemukan matematika. Treffers dalam Fauzan (2002) aktivitas yang disajikan dalam pembelajaran matematika realistik adalah: 
"An activity of solving problems, of looking for problems, and also an activity of organizing a subject matter. This can be a matter from reality, which has to be organized according to mathematical patterns if they have to be solved. It can also be a mathematical matter, new or old result, of your own or ohters, which have to be organized according to new ideas, to be better understood, in a broader context, or by an axiomatic approach"

Menurut Gravemeijer (1994;1997) dan Treffers (1991a) dalam Fauzan pengorganisasian aktivitas ini yang disebut matematisasi. Dalam Heuvel dan Panhuzen (2003), menurut Treffers ada 2 cara matematisasi dalam pembelajaran matematika yaitu matematisasi horisontal dan matematika vertikal. Matematisasi horisontal adalah pembelajaran matematika dimulai dunia kehidupan real menuju dunia simbol, sedang matematisasi vertikal pembelajaran matematika dimulai dari simbol-simbol menuju simbol-simbol.

Sedang menurut de Lange(1996) dalam Fauzan menggambarkan proses konseptual matematisasi dalam pembelajaran matematika realistik adalah proses pengembangan konsep matematika dan ide matematika mulai dari kehidupan real, dan pada akhirnya kita memerlukan refleksi pemecahan pada kehidupan real kembali.

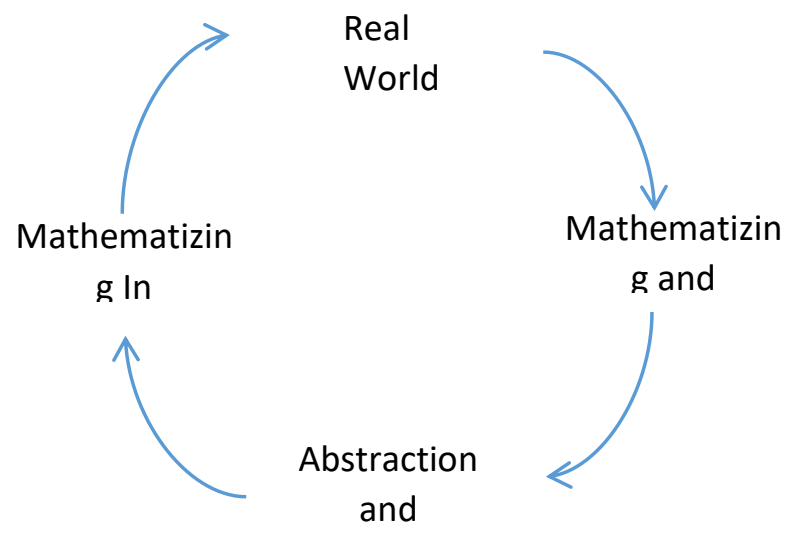

Gambar 1. Konseptual matematisasi (de lange dalam fauzan, 2002)
Menurut Treffers dalam Zulkardi (2010) ada 4 klasifikasi pembelajaran matematika yaitu 1) Pendekatan mechanistic atau pendekatan traditional yaitu pembelajaran matematika berdasar pada latihandril dan pola, yang memperlakukan manusia seperti computer atau mesin. Ini artinya aktivitas siswa dalam pendekatan ini berdasarkan memori pola atau algoritma. Kesalahan akan terjadi jika siswa dipertemukan dengan masalah lain yang berbeda dari memori yang mereka punya. Dalam pendekatan ini baik matematisasi horisontal maupun vertikal tidak digunakan. 2) Pendekatan empiris , pembelajaran matematika dimana siswa disiapkan dengan materi materi dunia kehidupannya. Ini artinya siswa dipertemukan dengan situasi situasi yang harus dilakukan dengan aktivitas matematisasi horisontal. Oleh karena mereka tidak ditujukan untuk meluaskan situasi menjadi sebuah model atau formula. 3) Pendekatan strukturalis, atau pendekatan baru berdasar pada teori himpunan, flowchart, dan beberapa permainan yang merupakan matematisasi vertikal. 4) Pendekatan realistik,pendekatan dimana situasi kehidupan real atau masalah kontektual sebagai titik awal pembelajaran matematika. Kemudian siswa bereksplorasi dengan kegiatan matematisasi horisontal, yaitu dengan mengorganisasikan masalah, mencoba mengidentifikasi aspek-sapek matematika dalam masalah dan menemukan aturan-aturan serta hubungan-hubungan, kemudian dengan menggunakan matematisasi vertikal siswa mengembangkan konsep matematika.

Tabel 1 Four Types of Mathematics Educations (Freudhenthal : 1991)

\begin{tabular}{|l|l|l|}
\hline Type & $\begin{array}{l}\text { Horisontal } \\
\text { Mathemat } \\
\text { ization }\end{array}$ & $\begin{array}{l}\text { Vertical } \\
\text { Mathemat } \\
\text { ization }\end{array}$ \\
\hline Mechanistic & - & - \\
\hline Empiristic & + & - \\
\hline Structuralist & - & + \\
\hline Realistic & + & + \\
\hline
\end{tabular}




\section{Prinsip - prinsip Realistic Mathematic Education}

Ada 6 prinsip dalam pembelajaran dengan RME menurut Treffers, yaitu; 1) The activity priciple, artinya bahwa dalam RME siswa diperlakukan sebagai partisipan aktif dalam proses pembelajaran. Hal ini menekankan bahwa matematika paling baik diajarkan dengan mengerjakan matematika, yang diinterpretasikan sebagai 'human activity' sebagaimana ide matematisasi dari Freudenthal dan Treffer. 2) The Reality principle, ada dua cara yaitu pertama, dengan menunjukkan pentingnya tujuan pembelajaran matematika memasukkan kemampuan siswa untuk menerapkan matematika dalam penyelesaian masalah kehidupan real. Atau kedua dengan memulai pembelajaran matematika dengan situasi masalah yang berguna bagi siswa, dengan memberikan peluang yang menantang kepada siswa untuk mengkonstruk dan mengembangkan matematika ketika memecahkan masalah. 3) The level principle, menggarisbawahi bahwa belajar matematika berarti siswa lulus berbagai tingkat pemahaman; dari informal contextrelated solution, melalui penciptaan berbagai tingkat pintas dan schematizations untuk memperoleh wawasan tentang bagaimana konsep dan strategi yang terkait dihubungkan. model penting untuk menjembatani kesenjangan antara informal, matematika yang berhubungan dengan konteks dan matematika yang lebih formal. untuk memenuhi fungsi bridging ini, model, harus bergeser dari 'model of' ke 'model for'. 4) The interwinement principle, siswa disajikan masalah sehingga siswa menggunakan alat dan pengetahuan matematika yang variatif. 5) The interactivity principle, bahwa dalam RME pembelajaran tidak hanya berupa kegiatan individu tetapi juga kegiatan kelompok, sehingga dalam pembelajaran dengan RME harus ada diskusi kelompok dan kelompok kerja yang memberikan peluang untuk berbagi strategi maupun ide dalam menemukan konsep matematika. 6) The guidence principle,dalam RME guru harus memiliki aturan yang pro active dalam pembelajaran siswa dan program pembelajaran harus berisi skenario dimana siswa mempunyai potensi untuk bekerja sebagai kunci siswa memahami. Untuk merealisasikan hal ini pengajaran dan program harus berdasar pada coherent longterm teaching-learning trajectories.

Sedangkan menurut Gravemeijer dalam Fauzan (2010:35-43) ada 3 prinsip heuristik dalam RME yaitu 1) Guided reinvention trought progressive mathematization, siswa harus diberi peluang untuk mengalami proses serupa dengan konsep matematika itu ditemukan. Ada 2 cara yang dapat ditempuh yaitu, dari sejarah matematika kita dapat belajar bagaimana konsep matematika itu dikembangkan, atau dengan memberikan masalah kontekstual yang memiliki penyelesaian dengan prosedur informal yang bervariasi, dilanjutkan dengan solusi prosedur matematisasi yang serupa sehingga siswa mendapat peluang untuk menemukan kembali konsep matematika. 2) Didactical phenomenology, implikasinya adalah desain pembelajaran dengan menyiapkan masalah kontekstual yang diambil dari fenomena real dan berguna bagi siswa. Kata real disini tidak selalu berarti objek real atau situasi disekitar tetapi seperti yang disampaikan oleh Gravemeijer berikut ini:

"the use label 'realistic' refers to a foundation of mathematical knowledge in situation that are experentially real to the student. Context in RME do not necessarily have to deal with authentic every-day life situations. What is central, is that the context in which a problem is situated is experientially real to students in that they can immediately act intelligently within this context. Of course the goal is that eventually mathematics itself can constitute experientially real context for the student".

3) Self Developed models, prinsip ini memainkan peranan penting dalam menjembatani perbedaan antara pengetahuan informal dan formal. Hal ini berimplikasi bahwa kita harus memberikan peluang pada siswa untuk menggunakan dan mengembangkan modelnya sendiri ketika menyelesaikan masalah. Pada awalnya siswa akan mengembangkan model yang familiar dengannya. Setelah proses 
generalisasi and formalisasi berangsurangsur akan menjadi satu kesatuan dalam dirinya. Proses transisi ini yang disebut dengan model off to model for. Menurut Zulkardi (2010) ada 5 dasar karakteristik dari pembelajaran matematika realistik yaitu; 1) phenomenological exploration or the use of context, dalam pembelajaran matematika realistik, pada titik awal harus memberikan pengalaman real bagi siswa, tidak memulai dengan sistem formal. Fenomena yang dalam konsep disajikan dalam realitas harus bersumber dari formasi konsep. Konsep disajikan dalam situasi konkrit yang dapat memaksa siswa untuk mengeksplorasi situasi, mencari dan mengidentifikasi matematika yang relevan, skematisasi, dan visualisasi untuk menemukan keteraturan, dan mengembangkan model yang menghasilkan dalam konsep matematika. 2) The use of models or bridging by vertical instrument, istilah model berarti situasi model dan model matematika yang dikembangkan oleh siswa sendiri. Ini berati bahwa siswa mengembangkan models dalam pemecahan masalah. Pada awalnya model adalah model situasi yang familiar dengan siswa, dengan process generalisasi dan formalisasi menjadi model matematika. Ada 4 model dalam rencana pembelajaran RME yang digambarkan sebagai berikut:

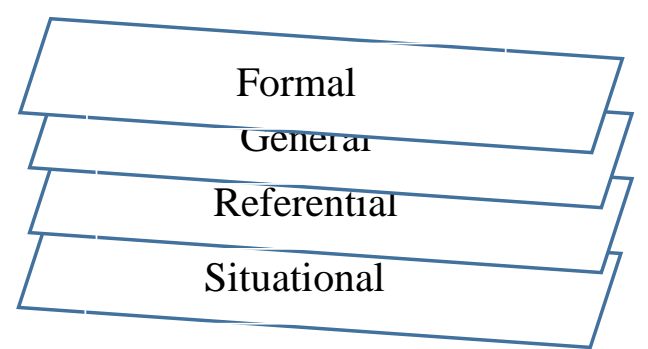

Gambar 2, Levels of models in RME

(Gravenmejer dalam zulkardi, 2010).

Adapun penjelasan level di atas yaitu; a) Situational level, level dimana domain khusus, situasi pengetahuan dan strategistrategi digunakan dalam situasi konteks. b) Referential level atau the level 'model of', level dimana model dan strategi untuk situasi dideskripsikan dalam masalah. c) $A$ general level or the level ' model for', level dimana fokus matematika pada strategi yang mendominasi reference pada konteks. d) The level of formal, level dimana satu pekerjaan dengan prosedure dan notasi konvensional.

3) The use of students own production and constructions or students contribution, siswa harus diminta menghasilkan sesuatu yang konkrit. Sebagai contoh siswa diminta menulis essay, melakukan percobaan, mengumpulkan data dan membuat kesimpulan, mendesain latihan yang dapat digunakan dalam test atau mendesain test untuk siswa yang lain dalam kelas. 4)The interactive character of the teaching process or interactivity, interaksi antar siswa dan antara siswa dengan guru merupaakan bagian yang penting dalam RME. 5) The intertwining of various lerning strands. dalam RME integrasi unit unit matematika penting. Ini biasa disebut dengan pendekatan holistik, yaitu menggunakan berbagai pengetahuan matematika dalam pembelajaran, sebagai contoh dalam kesebangunan dibutuhkan juga pengetahuan aljabar.

\section{Langkah Pelaksanaan RME}

Menurut Holisin (2007) berdasar prinsip dan karakteristik pembelajaran RME langkah-langkah yang harus dilakukan dalam kegiatan inti proses pembelajaran adalah

1) Memahami masalah kontekstual, yaitu siswa diberi masalah kontekstual dan siswa diminta memahami masalah tersebut.

2) Menyelesaikan masalah kontekstual, setelah memahami masalah siswa menyelesaikan masalah dengan caranya sendiri.

3) Membandingkan dan mendiskusikan jawaban,

4) Menyimpulkan.

Berdasar prinsip-prinsip dan karakteristik RME langkah-langkah pembelajaran yang dilakukan oleh peneliti adalah

1) Menyajikan masalah kontekstual dengan melakukan kegiatan tertentu. Siswa bekerja dalam kelompok menyelesaikan masalah dengan caranya 
sendiri. Kemudian refleksi atas hasil diskusi siswa.

2) Menyajikan kegiatan untuk mengkonstruk konsep matematika.

3) Menyajikan kembali masalah konstekstual menggunakan konsep matematika tersebut, serta membandingkan hasil jika dikerjakan dengan caranya sendiri dan konsep matematika yang sudah dikonstruk.

4) Menyimpulkan.

\section{Pembelajaran Kesebangunan}

Menurut Van Heile dalam Mason (2002) ada 5 level dalam memahami kesebangunan yaitu; 1) Visualisasi; siswa mengenali gambar dari penampilannya saja, sering mereka membandingkan dengan prototype yang mereka kenal. Sifat-sifat gambar tidak dirasakan. Pada levelan ini siswa membuat kesimpuan berdasarkan persepsi bukan penalaran. 2) Analisis ; pada levelan ini, siswa melihat gambar sebagai kumpulan sifat. Mereka dapat mengenali dan menamai sifat-sifat dari gambar kesebangunans, tetapi mereka tidak dapat melihat hubungan antara sifat-sifat ini. Pada level ini siswa dapat menyebutkan semua sifat-sifat yang dia ketahui tetapi tidak dapat melihat mana sifat yang perlu dan mana sifat yang tidak perlu untuk mendiskripsi suatu objek. 3) Abstraksi; siswa dapat melihat hubungan antar sifat dan antar gambar. Pada level ini siswa dapat membuat definisi dan memberikan argumen untuk menjustifikasi penalarannya. Implikasi logis seperti persegi bentuk khusus dari persegi panjang dapat dipahami. Tahu aturan dan pentingnya aturan deduksi formal tetapi belum memahaminya. 4) Deduksi; siswa dapat mengkonstruk bukti, paham aturan aksioma dan definisi, dan tahu makna syarat perlu dan syarat cukup. Pada level ini siswa harus mampu mengkonstruk bukti seperti yang biasa ditemukan pada kelas kesebangunan yang tinggi. 5) Rigor; pada level ini siswa paham aspek-aspek formal dalam deduksi seperti membuat dan membandingkan sistim matematika. siswa dapat memahami penggunaan bukti tidak langsung, bukti dengan kontrapositif dan memahami sistem non Euclid. Sedang Clement dan Battista menambahkan level ke 0, yang disebut dengan pre-recognition. Pada level ini siswa hanya dapat melihat bagian dari karakteristik visual dari bentuk, yang mengakibatkan tidak bisa membedakan gambar-gambar. Contoh siswa bisa membedakan segitiga dan segiempat tapi tidak bisa membedakan belah ketupat dan jajar genjang.

Menurut Hoong dan Khoh (2008:124128) ada 6 pendekatan dalam pembelajaran kesebangunan yaitu; 1) direct teaching, metode transfer pengetahuan secara langsung dari guru kepada siswa. 2) Deductive reasoning, pembelajaran matematika dimulai dari definisi, sifat-sifat, dan baru digunakan atau diaplikasikan. 3) Inductive reasoning and conjecturing, pembelajaran matematika dimulai dari kejadian kejadian khusus kemudian digeneralisasi menjadi sebuah definisi atau sifat. 4) Problem based, pembelajaran matematika dimulai dari penyajian masalah. 5) Applications to real world, pembelajaran matematika dapat disajikan dengan pemberian informasi kemudian penggunaan konsep tersebut dalam kehidupan seharihari. 6) Dynamic geometry software, pembelajaran kesebangunan dengan menggunakan software kesebangunan.

Merujuk pendapat para ahli di atas bahwa dalam pembelajaran kesebangunan dapat dilaksanakan secara deduktif, yaitu mengkonstruk konsep atau bukti, serta aplication to real world, yaitu pembelajaran matematika dapat disajikan dengan penggunaan konsep tersebut dalam kehidupan sehari-hari, Sedang dalam RME terdapat langkah untuk mengkonstruksi konsep serta menyajikan masalah kontekstual, sehingga pembelajaran dengan RME dapat diterapkan pada pembelajaran kesebangunan yang merupakan sub materi dari kesebangunan.

\section{Kerangka Berfikir}

Merujuk pada kajian pustaka di atas dapat diketahui bahwa pembelajaran kesebangunan termasuk di dalamnya materi kesebangunan dapat dilakukan dengan beberapa pendekatan. RME dikembangkan di Belanda dikembangkan berdasar teori Van Heile tentang tahapan-tahapansarankan Anda siswa memahami kesebangunan. 
Untuk memberikan pengalaman siswa dalam belajar matematika dengan menyelesaikan masalah dengan caranya sendiri, mengkonstruksi konsep matematika yang dipelajari, kemudian mengaplikasikan konsep dalam menyelesaikan masalah baik masalah matematika maupun masalah dalam kehidupan sehari hari, RME dapat memberikan pengalaman itu dan merupakan gabungan beberapa pendekatan dalam pembelajaran kesebangunan. Salah satu prinsip dalam RME adalah The activity priciple, artinya bahwa dalam RME siswa diperlakukan sebagai partisipan aktif dalam proses pembelajaran, sehingga pembelajaran dengan RME harus dilakukan dengan memberikan kesempatan kepada siswa untuk berinteraksi dengan guru dan teman, serta aktif melakukan kegiatan dalam menemukan konsep dan menyelesaikan masalah. Sehingga dengan RME siswa dapat aktif melakssiswaan pembelajaran.

\section{Hipotesis Tindakan}

Adapun hipotesis tindakannya yaitu pembelajaran matematika dengan RME dapat:

a. Meningkatkan keaktifan siswa dalam proses pembelajaran pada materi kesebangunan siswa kelas IX di MTs Negeri 2 Temanggung.

b. Meningkatkan hasil belajar siswa pada materi kesebangunan siswa kelas IX di MTs Negeri 2 Temanggung.

\section{METODE PENELITIAN}

\section{Metode penelitian}

Penelitian ini merupakan penelitian tindakan kelas. Pada penelitian ini dirancang melalui beberapa tahapan yaitu Siklus pertama; 1) tahap persiapan, meliputi pembuatan RPP, LKS, instrumen penilaian ketrampilan, instrumen penilaian pengetahuan, lembar observasi kegiatan guru, lembar observasi kegiatan siswa, lembar observasi keaktifan siswa dan angket pelaksanaan pembelajaran . 2) Tahap pelaksanaan, pelaksanaan penelitian dengan menggunakan RME digunakan prinsipprinsip seperti yang tertuang dalam kajian teori, yaitu bahwa dalam pembelajaran RME dilaksanakan dengan; a) Pertemuan pertama: pembelajaran pertama siswa disajikan masalah konstekstual berkaitan dengan kesebangunan bangun datar, siswa diberi kesempatan menyelesaikan menggunakan caranya sendiri. b) Dengan belajar kelompok agar dapat mendiskusikan pemecahan masalah. c) Pertemuan kedua menyajikan lembar kerja untuk membimbing siswa mengkonstruk/ menemukan syarat dua bangun datar sebangun. d) Pertemuan ketiga menyajikan masalah matematika atau masalah seharihari yang berkaitan dengan kesebangunan bangun datar agar dapat diselesaikan dengan formula atau konsep yang telah ditemukan. Pada tahap ini pula dilakukan observasi terhadap pelaksanaan pembelajaran baik oleh guru maupun oleh siswa. Observasi ini dilakukan oleh guru lain yang mengampu mata pelajaran yang sama. Observer ini ayang akan memberikan catatan-catatan atas pelaksanaan pembelajaran yang dilakukan. 3) Tahap Refleksi, pada tahap ini dilakukan dengan menganalisis hasil pelaksanaan baik dari catatan observer, lembar pengamatan keaktifan oleh observer, angket yang diisi siswa, maupun hasil penilaian pengetahuan sebagai bahan perbaikan, serta hasil analisis dibandingkan dengan indikator keberhasilan.

Siklus kedua; 1) tahap persiapan, meliputi pembuatan RPP, LKS, instrumen penilaian ketrampilan, instrumen penilaian pengetahuan, lembar observasi kegiatan guru, lembar observasi kegiatan siswa, lembar observasi keaktifan siswa dan angket pelaksanaan pembelajaran. 2) Tahap pelaksanaan, pelaksanaan penelitian dengan menggunakan RME digunakan prinsipprinsip seperti yang tertuang dalam kajian teori, yaitu bahwa dalam pembelajaran RME dilaksanakan dengan a) Pertemuan pertama: pembelajaran pertama siswa disajikan masalah konstekstual berkaitan dengan kesebangunan segitiga, siswa diberi kesempatan menyelesaikan menggunakan caranya sendiri. b) Dengan belajar kelompok agar dapat mendiskusikan pemecahan masalah. c) Pertemuan kedua menyajikan lembar kerja untuk membimbing siswa mengkonstruk/menemukan syarat dua segitiga sebangun. d) Pertemuan ketiga menyajikan masalah matematika atau 
masalah sehari-hari yang berkaitan dengan kesebangunan segitiga agar dapat diselesaikan dengan formula atau konsep yang telah ditemukan. Pada tahap ini pula dilakukan observasi terhadap pelaksanaan pembelajaran baik oleh guru maupun oleh siswa. Observasi ini dilakukan oleh guru lain yang mengampu mata pelajaran yang sama. Observer ini ayang akan memberikan catatan-catatan atas pelaksanaan pembelajaran yang dilakukan. 3) Tahap Refleksi, pada tahap ini dilakukan dengan menganalisis hasil pelaksanaan baik dari catatan observer, lembar pengamatan keaktifan oleh observer, angket yang diisi siswa, maupun hasil penilaian pengetahuan sebagai bahan perbaikan. serta hasil analisis dibandingkan dengan indikator keberhasilan.

\section{Obyek dan Setting Penelitian}

Penelitian ini dilakukan di MTs Negeri 2 Temanggung Kabupaten Temanggung Propinsi Jawa Tengah. Obyek penelitian ini adalah siswa kelas IX F MTs Negeri 2 Temanggung yang berjumlah 32 siswa.

\section{Variabel Penelitian dan Teknik Pengumpulan data \\ Data yang diperoleh dalam} penelitian ini adalah; 1) data keaktifan siswa dengan observasi 2) respons siswa terhadap pelaksanaan pembelajaran dengan angket 3) data hasil belajar yang terdiri dari nilai pemahaman konsep dan nilai penyelesaian masalah dengan tes.

Keaktifan siswa adalah kegiatan yang dilakukan oleh siswa selama pembelajaran, yang meliputi bertanya, mengerjakan tugas, dan mengemukakan pendapat. Respon siswa terhadap pembelajaran adalah pendapat siswa terkait dengan pelaksanaan pembelajaran dan masalah yang disajikan dalam pembelajaran. Hal ini dimaksudkan untuk perbaikan pembelajaran selanjutnya. Hasil belajar dibatasi pada hasil belajar pengetahuan.

\section{Teknik analisis data}

Data dianalisis dengan metode triangulasi dan deskripsi komparasi.

\section{Indikator Keberhasilan}

Indikator keberhasilan penggunaan pembelajaran ini adalah; 1) Jumlah siswa yang aktif dalam pembelajaran lebih dari atau sama dengan 75\%. 2) Jumlah siswa yang nilai pengetahuaannya sama atau di atas KKM (KKM 70) lebih dari 70\%. 3) Jumlah siswa yang nilai ketrampilannya sama atau di atas KKM (KKM 70) lebih dari $70 \%$.

\section{HASIL PENELITIAN DAN PEMBAHASAN}

\section{Hasil Penelitian}

Hasil penelitian dapat dilihat pada tabel berikut :

Berikut hasil keaktifan siswa dalam pembelajaran pada siklus I dan II :

Tabel 2 Data Keaktifan siswa dalam Pembelajaran

\begin{tabular}{llll}
\hline Kriteria & $\begin{array}{l}\text { Kondisi } \\
\text { Awal }\end{array}$ & Siklus I & Siklus II \\
\cline { 2 - 4 } Aktif & $19,4 \%$ & $69,4 \%$ & $94,4 \%$ \\
\hline
\end{tabular}

Berikut hasil penilaian pengetahuan pada siklus I dan II :

Tabel 3 Data Nilai Pengetahuan

\begin{tabular}{llll}
\hline Kriteria & $\begin{array}{l}\text { Kondisi } \\
\text { Awal }\end{array}$ & $\begin{array}{l}\text { Siklus } \\
\text { I }\end{array}$ & \begin{tabular}{l} 
Siklus \\
Nilai \\
\cline { 3 - 4 } 70
\end{tabular} \\
\cline { 3 - 5 } & $17 \%$ & $55,5 \%$ & $94,4 \%$ \\
\hline
\end{tabular}

Berikut hasil persentase jawaban benar untuk soal pemahaman konsep dan pemecahan masalah pada siklus I dan II :

Tabel 4 Data Persentase jawaban benar soal pemahaman konsep dan pemecahan masalah

\begin{tabular}{lll}
\hline Kriteria & $\begin{array}{l}\text { Rata-rata } \\
\text { Siklus I }\end{array}$ & $\begin{array}{l}\text { Rata-rata } \\
\text { Siklus II }\end{array}$ \\
\cline { 2 - 3 } $\begin{array}{l}\text { Pemahaman } \\
\text { Konsep }\end{array}$ & $76 \%$ & $87 \%$ \\
$\begin{array}{l}\text { Pemecahan } \\
\text { masalah }\end{array}$ & $68 \%$ & $68 \%$ \\
\hline
\end{tabular}

Berikut adalah hasil penilaian ketrampilan Tabel 5 Data Nilai Ketrampilan

\begin{tabular}{ccc}
\hline Kriteria & Siklus I & $\begin{array}{c}\text { Siklus } \\
\text { II }\end{array}$ \\
\cline { 2 - 3 } Nilai $\geq 70$ & $77,8 \%$ & $82 \%$ \\
\hline
\end{tabular}


Berikut contoh pekerjaan siswa dalam pembelajaran

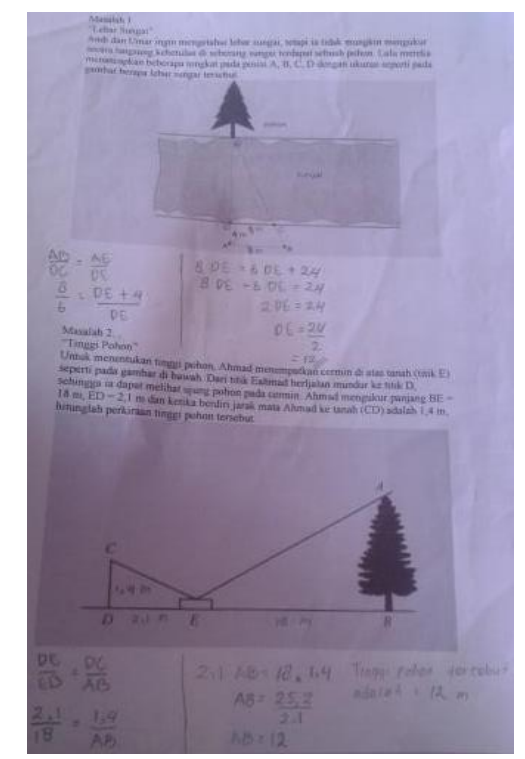

Gambar 3 Pekerjaan siswa

\section{Pembahasan}

Pada proses pembelajaran selama siklus 1 terdapat peningkatan keaktifan siswa dari yang tidak bertanya siswa mulai dapat bertanya, aktif dalam berdiskusi dalam kelompok, dapat menyelesaikan masalah lebih baik dari sebelumnya. Pada siklus 2 keaktifan siswa lebih meningkat dan siswa mulai terbiasa bekerja dalam kelompok dan mengkonstruksi pengetahuannya sendiri.

Dari tabel 2 dapat diketahui bahwa terdapat kenaikan antara sebelum tindakan ke siklus I dan dari siklus I ke siklus II.

Dari tabel 3 dapat diketahui bahwa kenaikan persentase jumlah siswa yang tuntas pada pengetahuan yang terjadi dari sebelum tindakan sampai siklus 2 meningkat. Nilai pengetahuan terdiri dari soal pemahaman konsep dan soal pemecahan masalah. Dari kategori tersebut diperoleh rata-rata persentase siswa menjawab benar adalah

Dari tabel 4 dapat diketahui bahwa terdapat kenaikan pada jumlah siswa yang dapat menyelesaikan soal pemahaman konsep. Sedang untuk pemecahan masalah tidak terjadi kenaikan. Hal ini disebabkan karena untuk soal pemecahan masalah pembiasaan latihan soal dan waktu yang lebih lama. Berikut salah satu contoh pekerjaan siswa pemecahan masalah.
Gambar 3 Salah Satu Pekerjaan siswa pada Pemecahan Masalah

Dari tabel 5 dapat dilihat bahwa terdapat kenaikan persentase siswa tuntas pada ketrampilan secara signifikan.

Selain gambaran proses pembelajaran data penelitian yang diperoleh adalah; 1) data keaktifan siswa pada siklus I banyak siswa yang aktif adalah 69,4\%. Hal ini menunjukkan bahwa pada siklus I belum memenuhi indikator keberhasilan sehingga perlu dilaanjutkan ke siklus II. 2) data hasil belajar ranah pengetahuan pada siklus I $55,5 \%$. Pengan persentase jawaban benar untuk soal pemahaman konsep $76 \%$ dan pemecahan masalah 68\%. Hal ini menunjukkan bahwa pada siklus I belum memenuhi indikator keberhasilan sehingga perlu dilanjutkan pada siklus II. 3) data nilai ketrampilan, pada siklus I mencapai $77,8 \%$ sudah mencapai indikator keberhasilan sehingga pada siklus II hanya untuk mengulang bagi yang belum memenuhi kriteria ketuntasan minimal.

Sedang untuk siklus kedua data penelitian yang diperoleh adalah; 1) data keaktifan siswa pada siklus pertama banyak siswa yang aktif adalah 94,4\% . Hal ini menunjukkan bahwa pada siklus II telah memenuhi indikator keberhasilan sehingga tidak perlu dilanjutkan ke siklus berikutnya. 2) data hasil belajar ranah pengetahuan pada siklus I 94,4\%. Dengan persentase jawaban benar untuk pemahaman konsep mencapai $87 \%$ dan pemecahan masalah $68 \%$. Hal ini menunjukkan bahwa pada siklus II telah memenuhi indikator keberhasilan sehingga tidak perlu dilanjutkan pada siklus berikutnya. 3) data nilai ketrampilan, pada siklus II mencapai $82 \%$ sudah mencapai indikator keberhasilan sehingga pada siklus ke 2 hanya untuk mengulang bagi yang belum memenuhi kriteria ketuntasan minimal.

\section{PENUTUP}

\section{Simpulan}

Dari hasil penelitian dan hasil diskusi di atas dapat disimpulkan bahwa; 1) pembelajaran RME pada kesebangunan di MTs Negeri 2 Temanggung dapat meningkatkan keaktifan siswa. 2) Pembelajaran RME pada kesebangunan di 
MTs Negeri 2 Temanggung dapat meningkatkan hasil belajar siswa.

\section{Saran}

Sedangkan saran yang dapat disampaikan yaitu; 1) pembelajaran RME dapat menjadi salah satu alternatif pembelajaran Kesebangunan untuk meningkatkan keaktifan siswa. 2)
Pembelajaran RMe dapat menjadi salah satu alternatif pembelajaran Kesebangunan untuk meningkatkan hasil belajar. 3) Pada saat pertama kali dilakukan siswa mengalami kesulitan akan tetapi pada siklus kedua siswa sudah merasa senang sehingga perlu dibiasakan. 3) Penelitian atau inovasi lebih lanjut dapat dikembangkan lagi.

\section{DAFTAR PUSTAKA}

Ahmad Fauzan, 2002, Applying Realistic Mathematics Seducation (RME) in Teaching Kesebangunan in Indonesiaa Primary Schools, Press: PrintPartners lpskamp,Enschede, diunduh di: http://doc.utwente.nl

Ali Mahmudi, 2009, Mengembangkan Kemampuan Berfikir siswa melalui Pembelajaran Matematika Realistik, Prosiding Seminar Nasional Penelitian, Pendidikan dan Penerapan MIPA, diunduh di: https://sciencemathematicseducation.files.wordpress.com

Dickinson,Paul, and Hough, Sue, 2012, Using Realistics Mathematics Education in UK Classroom, Booklet, diunduh di: http://www.mei.org.uk/files/pdf/rme impact booklet.pdf

Erman Suherman dkk, 2001, Strategi Pembelajaran Matematika Kontemporer, jurusan Pendidikan Matematika Universitas Pendidikan Indonesia Bandung

Iis Holisin (2007), Pembelajaran Matematika Realistik (PMR), Jurnal Didaktis Vol. 5, No. 3 hal 1-68 Oktober 2007.

Leong Yew Hoong and Lim-Teo Suat Khoh, 2008, Teaching Geometry, dalam Lee Peng Yee, Teaching Secondary School Mathematic, A Resource Book, Mac Graw Hill: Singapore

Mason Marguerite (2002), The Van Heile leves of Kesebangunanc Understanding, Professional Handbook for Teacher, Geometry : Exploration and Application, diunduh di: http://jwilson.coe.uga.edu/EMAT8990/GEOMETRY

Sarwiji Suwandi 2009, Penelitian Tindakan Kelas dan Karya Ilmiah, PSG Rayon 13 Surakarta

Supinah, Bagaimana Mengukur Aktivitas siswa dalam Pembelajaran, Makalah, diunduh di: http://p4tkmatematika.org/file/ARTIKEL

Sri Wardani, 2010, Teknik Pengembangan Instrumen Penilaian Hasil Belajar Matematika di SMP/MTs, Bahan Ajar Diklat Guru Pemandu/Inti/Pengembang Matematika SMP Jenjang Dasar 2010, Diunduh di: http://file.upi.edu/Direktori.

Theresia Laurens , Florence Adolfina Batlolona , John Rafafy Batlolona and Marleny Leasa (2017), How Does Realistic MathematicsEducation(RME)Improve Students'Mathematics Cognitive Achievement?, Eurasia Journal of Mathematics, Science and Technology Education, diunduh di: https://www.ejmste.com

Van Heuvel, Marja, and Drijver, Paul, 2013, Realistic Mathematics Education, Encyclopedia of Mathematics Education, Diunduh di: https://promathmedia.files.wordpress.com

Zulkardi, 2010, How to Design Mathematics Lesson based on The Realistic Approach, Makalah, diunduh di: http://p4mri.net 